\title{
Explaining job insecurity for temporary agency workers: A comparison between Sweden and Belgium
}

Hakansson Kristina, (University of Gothenburg - Sweden)

Pulignano Valeria (CESO- KU Leuven Belgium)

Isidorsson Tommy (University of Gothenburg - Sweden)

Doerflinger Nadja (CESO- KU Leuven Belgium)

Accepted for Publication in Economic and Industrial Democracy (2018)

\section{Introduction}

Temporary agency work is often used as an indicator of the degree of flexibility in the labour market. This is because temporary agency work can provide flexibility for employers while at the same time offering some security to the agency workers through a sequence of different (short-term) job assignments, not necessarily with the same client organization. Current research has critically shed light on the insecurity characterizing temporary agency work, which is considered as likely to entrap individuals in precarious work conditions (Standing, 2011; Kalleberg, 2009; Håkansson, Isidorsson and Kantelius, 2012; Håkansson and Isidorsson, 2015). It is argued that structural contexts and social policy differences across (and within) diverse national institutional settings contribute to the insecurity of agency workers by differentiating social policy and benefits (e.g. pensions, childcare, sickness, unemployment) as well as working conditions, wages and 
types of employment contracts between agency and regular workforces (Burroni and Carrieri, 2011; Emmenegger et al., 2012).

Although several studies point to the insecurity of agency work, only a few have focused to date on understanding how different regulatory contexts concur to shape such insecurity (Forde and Slater, 2013; Pulignano and Doerfinger, 2013; Doerfinger and Pulignano, 2015). In particular, these studies have showed that employment and industrial relations institutions can deepen or relax the insecurity divide between different groups of workers. For example, institutional settings where unions are stronger (Chung, 2016) and where bargaining structures are more encompassing (Pulignano and Doerfinger, 2017; Benassi et al., 2016) can protect workers to insecurity. Similarly, different employment regulatory models can influence insecurity by fostering or hindering employers to balance their flexibility preferences, thereby enhancing or reducing insecurity for workers, within the context of the contemporary shifting of national regulatory constraints (McKenzie et al., 2010).

This article aims at explaining how regulations on national and sectoral levels influence the way social protection for agency workers is guaranteed at the workplace level, and thereby contributing to shaping insecurity of those workers. By comparing two similar workplaces of large companies in Sweden and Belgium, the article assess how different social arrangements for agency work, including both regulatory settings at national (industry) level and the collective practices of representation of agency work at local levels can explain the experience of insecurity for agency workers. The two countries represent different employment relation systems, they differ in the regulation of the 
temporary agency work and in the representation structure. Hence, the choice of Sweden and Belgium is suitable for a comparative analysis.

\section{The research in context}

Temporary agency work is based on the triangular relationship consisting of the 'employment' relationship between the agency worker and the agency, the 'management' relationship between the agency worker and the client organization and the 'business' relationship between the client organization and the temporary work agency (Bergström and Storrie, 2003: 9; Storrie, 2007: 106; Håkansson et al., 2012) (Figure 1). The 'employment' relationship deals with employment conditions such as the contract and wages, and the development of the competences of the employee. The 'management' relationship concerns factors in the day-to-day working situation, for example, job characteristics and agency workers' integration with the employees within the client organization. The 'business' relationship between the temporary work agency and the client organization is such that the client organization buys labour from the temporary work agency temporarily or until further notice. In sum, workers are employed by (contractually linked to) the agency, but they work at the client organization.

Figure 1 about here

The 'employment', the 'management' and the 'business' relationships are all considered important when examining how temporary agency workers' experiences of insecurity are shaped in local workplaces. Several studies illustrate that within the triangular relationship temporary agency workers experience lower security when compared with permanent workforce. This is also when the traditional sociological categories of age, 
gender, educational level and occupational group are taken into consideration (Aletraris, 2010: 1144; De Cuyper, Notelaers and De Witte 2009; de Graaf-Zij1, 2012; Forde and Slater, 2005; Håkansson et al., 2012; Morris, 1999). The business relationship entails possibilities for the client organization to dictate the terms and conditions, which could include demands regarding who will be contracted for the work and who is deemed unsuitable. Thus, the union's standpoint is that employment protection is, in practice, weaker in the temporary agency sector than in other industries (Björkemarken, 2012). Several studies from different perspectives have tried to investigate the factors explaining the low level of security for temporary agency workers. Aside from the contractual differences that naturally attain a lower level of security for temporary agency workers vis-à-vis the permanent workforce, literature on the traditional contract has also shown that the employment contract, together with age and training, accounts for the perceived job insecurity of the agency workers (Håkansson A et al., 2012; Hall, 2006). However, empirical results in Sweden reveal that differences may exist across professions, with nurses employed by temporary work agencies experiencing the highest level of security (Allvin, Jacobsson and Isaksson 2003).

Håkansson, Isidorsson and Strauss Raats (2013) also illustrate that job insecurity is a major psychosocial issue for the temporary agency work industry. Job security could be defined as "the certainty of retaining a specific job with a specific employer" (Leschke et al. 2007: 340). Gazier (2007: 102) draws on the definition by Leschke et al. (2007) but he formulates it as "granting the continuation of the same job." Accordingly, job security connects to the actual employer and the possibility of remaining in the job with that employer. Even though open ended contracts for temporary agency workers are feasible from a legal point of view in quite many countries, temporary contracts are widespread 
(OECD 2013:89). The perceived job insecurity in the temporary agency industry is therefore hardly surprising. Regalia (2013) discusses different kinds of security for employees with non-standard work. She offers a classification of interventions that aim to ensure security for employees on non-standard contracts. One type entails a gradually transfer to standard employment contract, thus reaching job security in the end. This transfer implies a pact between the union and employer where also employment conditions for the ordinary staff might be affected. Another type of gaining security is by being engaged by different employers, exactly the idea of temporary work agencies. Theoretically, this type entails high job security in case the agency worker has an open ended contract and the work agency can provide for new assignments.

Furthermore, aside from the relevance of the contractual differences between regular and agency work, research also points out that temporary agency workers may lack workplace representation by trade unions, something that employees in regular work may not, which could affect their sense of security. This is because trade unions experience difficulties in organizing agency work, which may be the result of unions not addressing issues relevant for this particular group of workers (Holst, Aust and Pernicka., 2008; Croucher and Brewster, 1998). Specifically in this regard, Heery (2004) proposes a typology of different union responses towards temporary agency work. In particular, by rejecting the analytical categories of union inclusion and union exclusion, which he considers too simplistic, he elaborates a much more in-depth classification of union approaches towards temporary agency work. Heery (2004) distinguishes between exclusion, regulation, replacement and engagement. Exclusion means a rejecting attitude towards temporary work agencies and an excluding attitude towards temporary agency workers/consultants. According to this response, the unions oppose temporary work agencies and do not see employees in that industry as legitimate members of unions. Regulation entails the union 
having an accepting attitude towards the industry but an excluding attitude in relation to the employees of the temporary staffing industry. This is a response that safeguards and defends the interests of the core workforce. Replacement implies a dismissive attitude by the union towards temporary work agencies but an including attitude towards employees of the industry. Engagement entails the union having an accepting attitude towards temporary work agencies and an including attitude towards agency workers/consultants. In this response, the unions aspire to improve the conditions of temporary agency labour.

Likewise, in a case study of a Swedish company, Bergström and Styhre (2010) show how the union can simultaneously be against using temporary agency workers in principle but accept them in practice. This could be understood as the trade unions attempting to protect their political influence when negotiating on labour market policies and employment dismissals for workers at the macro level (Davidsson and Emmenegger, 2013). Thereby, when this occurs, they may engage less in retaining membership at the micro level (Schmitter and Streeck, 1999). This is in line with Olsen's (2005) claim that unions' different responses at local and national levels are worth looking at in order to develop a better analysis of unions' responses to agency work. Overall, these studies illustrate that the unions at national and local levels might have different agendas for how to deal with temporary agency work. This is relevant if we want to understand how security via the union channel is guaranteed to agency workers, since at national level, the unions could have influence on the regulation, while at the local level, works councils and trade unions may adopt different strategies in dealing with temporary agency workers. These strategies are often the response to the corporate strategy of using temporary agency work (Pulignano and Signoretti, 2016) either as a buffer in case of a downturn or for extensive long-term use (Purcell, Purcell and Tailby 2004; Elcioglu, 2010; Kalleberg and Marsden, 
2005). Holst, Nachtwey and Dörre (2010) also discern a new way of using agency workers, whereby assignments have no fixed termination date.

As illustrated above, temporary agency workers may experience insecurity at work. This can be related to the short-term nature of the contract as well as to the differences in the way agency work is regulated by law. Moreover, agency workers may have difficulty in being collectively represented by the unions at the workplace. It is often reported that agency workers are much more in need of voice and representation than regular workers (Heery, 2004; Håkansson and Isidorsson, 2014). What is less known so far is how the regulatory system at national level takes the shape of union representation practices at workplace levels and how these practices impact agency workers' job security. Trade unions are the traditional channel for employees' voices. Due to the fact that agency workers have dual (or split) employment and management relationships, the traditional form of representation at work, which entails that workers are represented in one workplace and organized by the same union, might not be accessible to them.

In this article, we aim to go beyond the obvious link between temporary contract and job insecurity and focus on how insecurity is shaped in different regulatory contexts. This approach entails a multi-dimensional understanding of insecurity where job insecurity and representation insecurity are closely intertwined.

\section{The regulation of agency work: Sweden and Belgium compared}

As this section will illustrate, comparing Sweden and Belgium is crucial, as agency work is differently regulated in the selected countries and the systems for collective representation of agency workers is also different. Although the working conditions in 
the agency industry are regulated via collective agreements in the same way as in any other industry in Sweden and Belgium, there are some remarkable differences in the way agency work is used and represented.

\section{Sweden}

Since 1993 it has been legal in Sweden to run private work agencies for profit-making purposes (Swedish Code of Statutes, 1993:440). The number of employees in the temporary work industry increased from some 5,000 in 1994 to 74,000 in 2015 (Bemanningsföretagen, 2006; 2009; 2011-2016). The increase in agency workers has been steady with the exception of first half of the 2000s and in conjunction with the economic crisis during 2008-2009, but recovered soon after. Data from Statistics Sweden (SCB 2014: 252) shows that those who are employed in the temporary work industry is equivalent to $1.6 \%$ of all employees. According to the statistics from the International Confederation of Private Employment Services (CIETT), long contract periods dominate in Sweden. According to the international employer organization, almost all contracts last a month or longer, and 70\% of all assignments last longer than three months (Ciett, 2013, 2014).

The operations of temporary work agencies in Sweden are regulated by the Private Employment Agencies and Temporary Labour Act (Swedish Code of Statutes, 1993:440, 2012:854). There are no restrictions regarding motives for using temporary agency workers, in neither the length of time nor the cumulative duration of assignments. The regulation of the agency work industry is weak in Sweden (OECD, 2013). However, there is also legislation in Sweden protecting the employees in the agency industry (Swedish Code of Statutes, 1993:440, 2012:854). This legislation explicitly emphasizes that 
employees may not be prevented from being employed by the client organization they are assigned to. Working conditions in the Swedish agency industry are regulated via collective agreements in the same way as other industries. Although there is no legislation regarding minimum pay for agency workers, according to the 2016 collective agreement between Swedish Staffing Agencies and the 14 unions of the Swedish Trade Union Confederation, temporary agency workers must have an hourly wage corresponding to the average hourly wage for comparable groups at the client organization (Staffing Agreement, 2016, Section 3, Subsection 2). The collective agreements also state the right to pay for temporary agency workers between assignments. This compensation payment is approximately $80-90 \%$ of the regular salary. This compensation is possible in a few other countries, although sometimes at a low level (OECD, 2013). Moreover, the Swedish Employment Protection Act (Swedish Code of Statutes, 1982:80), which in Sweden prescribes that the normal form is an open-ended employment contract normally called a permanent position, applies also to employees of the agency industry. Hence, in Sweden a temporary agency worker can have a permanent employment contract with a temporary work agency.

Trade union density in Sweden is high from an international perspective. Even though there was a substantial drop in union membership in the mid-2000s, due to raised fees for union unemployment funds (Kjellberg, 2011), union density is still 70\% (Kjellberg, 2016). However, trade unionists estimate that union density is significantly lower in the temporary staffing industry. Also, it is quite uncommon to find local branches at temporary work agencies (Björkemarken, 2012). Also, if there are local trade unions at the temporary work agency it is difficult to organize trade unions activities since members are on assignments at different client organizations (Håkansson and Isidorsson 2014). 
When it comes to union membership, agency workers are organized where they have their employment relationship, which is the work agency. The union branch organizing agency workers depends on the business focus for the work agency. If the agency's business focus is logistics the temporary work agency would be organized by transport workers union, and if its focus is manufacturing the metal workers union would normally organize workers at the agency. Since temporary agency workers are assigned to workplaces in different industries, it is not obvious which trade union that should organise agency workers. Furthermore, agency workers and client organization employees working in the same work-place sharing the same work tasks may be organized by different trade unions.

Workplace representation for employees in Sweden is regulated along a single channel of representation, which means that it is through the local union at the workplace, i.e. in case of the agency worker, the workplace is the temporary work agency - not the client organization. In work agencies where there is no local union branch, the organized agency worker can turn to the regional ombudsman. Legislation requires the employer to inform and negotiate with the unions at the workplace before making major changes at the workplace including termination of employment contracts, and many of the practical arrangements for doing so, which elsewhere in Europe are fixed by law, are left in Sweden to local negotiations. Moreover, in accordance with the Co-determination at Work Act (MBL), unions at the workplace have the right to negotiate with an employer on any matter relating to the relationship between the employer and any member employed by the organization, which in a client organization does not include agency workers on assignment. The Trade Union Representatives (Status at the Workplace) Act (Swedish Code of Statutes, 1974:358) states that the appointed union representative has 
the legal right to represent employees employed by the employer at the workplace (Section 1). This imply that it is difficult for the union representative at the client organization to represent an agency worker, as in accordance with the triangular relationship characterizing the agency sector, she/he is not employed by the same employer (see Figure 1). Thereby, to secure union representation there has to be a local union at the agency, representing the temporary agency workers. However, as previously noted, it is quite uncommon to find local union branches at temporary work agencies and practical difficulties to organize union activities since agency workers are on assignments.

\section{Belgium}

Temporary work agencies are the prevalent type of private employment agencies in Belgium. They are often part of international human resources (HR) groups offering their clients so-called 'one-stop-shopping', whereby client organization can get diverse services at one agency. Nonetheless, various other employment placement agencies exist, such as recruitment agencies, selection agencies, outplacement agencies and headhunters. The conditions for private employment agencies are regulated by both federal and regional authorities, each according to their own jurisdiction.

The penetration rate of agency work in Belgium was 2\% in 2011 (CIETT, 2013). According to CIETT (2014) statistics, in comparison with 2013 (when the activity of the agency industry stood at $11.95 \%$ in comparison with other industries) the activity in the temporary agency work industry in 2014 in Belgium grew by $9.22 \%$, resulting from a rise in the blue-collar segment. Despite the growth, however, Belgium features the lowest growth of temporary agency workers in Europe. It may be argued that the widespread use 
of other forms of internal flexibility (e.g. temporary unemployment schemes) available for management and trade unions at the workplaces in accordance to law discourage companies from using a higher proportion of agency work in Belgium (Pulignano and Doerfinger, 2013; Houwing and Vandaele, 2011).

The Belgian legislation for temporary work agencies is very restrictive. Agencies need a licence to be active in the Belgian labour market, even if the agency is not headquartered in Belgium, which is not necessary for other private employment agencies such as placement agencies. The application procedure is organized at a regional level. The 1987 Act regulates the use and conditions of temporary agency workers. When a temporary work agency sends a worker to a client organization, the agency nevertheless remains responsible, together with the client, for paying the wages, indemnities and social security contributions. The law prohibits the agency from conducting any other activity parallel to placing workers at the disposal of client organizations. Agencies can only contract workers, and not self-employed persons, to perform temporary work. The recognition of temporary work agencies falls within the competence of the regions (the Flemish, Walloon and Brussels regions). Accordingly, each of the regions has an advisory committee on which the trade unions and employers have several representatives and on which they have an advisory capacity concerning the recognition, suspension or withdrawal of agencies' licences. The conditions for recognition are to a large extent similar for the three regions. Each region is responsible for the implementation of the EU Directive on Agency Work.

Belgium is one of the most regulated markets for agency work in Europe. The agency firm employs the temporary worker, with all of the national obligations of labour law and 
social security law that this involves. Moreover, the Act of 1987 is to a large extent complemented by national-, sectoral- and firm-level collective agreements in both private and public sectors. Accordingly, conditions for hiring out employees to another enterprise or recruiting temporary workers are strictly defined by law, while working conditions of the temporary workers are guaranteed by law to be similar to any other workers executing the same job in the same company (equality principle). However, open ended contracts are not possible for temporary agency workers in Belgium.

Sectoral bargaining involving trade unions and employers' associations of work agencies exists in Belgium. In particular, agency work is formally recognized as an industry in Belgium, with a joint committee (JC, 322). The law foresees specific conditions and procedures regulating the use of temporary work, particularly in the situation of temporary increase in workload. The maximum duration is agreed between the client organization and the workers' representation body, and in any case, cannot be more than six months. It can be extended for another six months with the authorization of the Fund for Social Security (Clauwaert, 2000). Generally, only five motives for using agency work are allowed in Belgium (according to the Labour Agreement 108): to replace a permanent employee, for example, in the case of sickness; to accommodate a temporary increase of work volumes; to meet exceptional/seasonal work needs; to achieve a predefined employment trajectory; and to allow for the intake of new staff.

Recently, new regulations have been enforced in Belgium to improve working conditions, increase employment opportunities and prevent abuses of agency work. At a time when the EU Directive encourages European governments to remove unnecessary restrictions, the Belgian legislation generates additional responsibilities for employers 
using agency workers. Accordingly, from 2013 onwards temporary agency work is be used by client organisations in Belgium as a 'stepping-stone' to directly hire the agency worker (on a fixed-term or permanent basis) after six months. However, client organisations are obliged to motivate their use as such.

As in Sweden, Belgian unions are involved in social security management through handling unemployment funds as part of the 'Ghent system' (Vandaele, 2006). This contributes to the relatively high union density (53\%), particularly among agency workers, who are unionized at a rate of about 64\% in Belgium (Arrowsmith, 2006; Delbar and Léonard, 2002). Belgian unions have a strong presence in the workplace, especially in large firms, via union-dominated works councils and trade union delegates. Workplace representation in Belgium runs through two separate channels: the works council (Comité d'enterprise or Ondernemingsraad) within larger workplaces (above 100 employees) and the trade union delegation that represents trade unionists in companies with at least 50 employees. Only trade unions are able to nominate members to the works council and negotiate key issues with management. However, the works council has extensive information and consultation rights, and although it is a joint body with an employee majority, it has decision-making powers in some areas, such as restructuring. The national 1981 collective agreement allows the establishment of a trade union delegation in the work agencies to represent the rights of the temporary workers within the agency. Moreover, agency workers have rights of representation at the client organization, too, where their numbers are taken into account to determine the necessary threshold of employees to the settlement of works councils.

Comparing Sweden and Belgium: A summary 
Sweden and Belgium differ in several aspects. In Sweden, the use of agency work is of a 'permissive' (liberal) form, since it is possible to use temporary agency workers for any reason and for unlimited time, while in Belgium the use is strictly regulated (restrictive). However, while job security is guaranteed by the Employment Protection Act in Sweden, which prescribes permanent employment for agency workers, this is not the case in Belgium, where job security is not guaranteed by law as a way to make the use of agency workers something temporary. In addition, union representation of agency workers in Sweden is regulated through the agency firm where they have their employment relations; in absence of a local trade union organization agency workers are represented by a regional ombudsman. Conversely, in Belgium, agency workers have representation rights at both the client organization and the agency.

Table 1 summarizes the features of the regulation of agency work in Sweden and Belgium. It incorporates the regulation for the use of agency work as well as its local regulation through the collective structures of workplace representation.

\section{Table 1 about here}

The empirical questions this paper engages with are how these different institutional configurations turn out at workplace level and in representation practices, and how these practices in turn affect the insecurity of agency workers. The following sections will present the findings of a cross-national study in Sweden and Belgium shedding light on the experiences at work regarding insecurity of agency workers within two similar workplaces in the manufacturing industry. 


\section{Research design and methodology}

The article is based on a cross-national comparative case study methodology. Two similar cases in Sweden and Belgium were examined to understand how differences regarding the regulatory and representation structures of agency work in two similar workplaces affected workers' (in)security. Case study research is highly suitable in this respect, because it allows for examining social processes in a particular setting (Eisenhardt, 1989). The selected cases belong to the manufacturing sector; they share a similar nature of the production process and technology, and they both make use of agency work. Moreover, the workplaces are highly unionized. Table 2 illustrates the cases' main characteristics (see Table 2).

The Swedish case is part of a multinational corporation within the automotive industry and has operations worldwide. It is a medium-sized production unit (approx. 500 employees), with day-to-day operations consisting of assembly work as well as some R\&D. Most of the employees have a long tenure. Production is organized into separate flow systems, where each flow consists of a number of workstations with up to four workers per workstation. Production is based solely on customer demand, entailing that demand can fluctuate on short notice. Agency workers need one week of on-the-job training for one work task; thereafter, they gradually learn more work tasks to be able to take part in job rotation.

The Belgium case belongs to a US multinational company operating as an automotive supplier. It employs about 25,000 staff globally, of whom more than half are blue-collar workers. The company manufactures low-tech products, using highly automated production processes involving many low-skilled tasks at the assembly line. The 
workplace - employing 1600 staff (about 1000 in production) - thus needs to offer quality products at low cost, delivered just-in-time. Customers can specify demand volumes on a weekly basis, which causes high flexibility needs on short notice, which are partially covered by using agency workers. Agency workers are trained on the job, and they learn different tasks so as to work in job rotation. Table 2 summarizes the features of the two cases.

Table 2 about here

Data were collected mainly through semi-structured interviews. Regarding the Swedish case, we performed interviews with key actors at four times: 2008, 2011, 2015 and 2016. Thus, it is possible to describe the case in a longitudinal perspective. Union representatives, HR managers and production managers and employees were interviewed as well as the manager at the temporary agency, temporary agency workers and ombudsmen at the regional union office. Hence, we interviewed all the key actors involved in issues about agency workers' assignments, job security and union representation. All interviews lasted 60-120 minutes and were recorded. All interviews were summarized and the summaries sent to the respective interviewees for approval. The interviews were also partly transcribed. In total, we conducted 17 interviews.

For the Belgian case, we conducted 30 semi-structured interviews in total during the period 2008-2013 with European HR managers, local HR managers, works councillors and trade unionists as well as the manager at the temporary agency, temporary agency workers and ombudspersons at the regional union office. As all major actors involved in workplace regulation of agency work were interviewed, we were able to draw a 
comprehensive picture regarding local policies and practices as well as corresponding negotiation processes. In addition, we also interviewed specialists for agency work at the sector level to get a better view on overall developments in the agency work sector and the regulation of this form of work at different levels. All interviews took between 60 and 120 minutes and were transcribed and subsequently analysed with the help of NVivo. The analysis also involved documentary materials (e.g. collective agreements at different levels, and company and union documents) collected during field work.

\section{Temporary agency work in Swedish and Belgian workplaces}

\section{Evidence from the Swedish case}

The plant has been using temporary agency workers on a fairly regular basis ever since 2004. In connection to the economic crisis of 2008 , the client organization had to reduce staff. The temporary agency workers were the first to leave the company. Thereafter, the company also had to give notice to approximately $10 \%$ of its own employees. In January 2010, the client organization's sales started to recover and demand continued to grow, reaching higher production levels than during the years prior to the crisis. In the wake of the financial crisis, the corporate executive board forced local plants to provide for $30 \%$ flexibility. This was achieved mainly by using temporary agency workers. At the time we conducted the research, the agency workers constituted a buffer, easy to terminate in case of a downturn.

When this [hiring of agency workers] started again, it was a way to avoid dismissals .(HR manager SE) 
In the spring of 2011 temporary agency workers constituted about one third of the bluecollar workforce. The long-term strategic use of agency workers allows first-line managers to handle day-to-day short-term absences in the entire workforce by deploying both regular employees and agency workers where there is a gap in the production line. To be able to fill the needs at different workstations, the client organization has to maintain and develop the skills and competences of the agency workers. For the agency workers, this means that they can keep up or even develop the competence level and thus increase their employability. Since 2011 some 50 temporary agency workers have been directly employed by the client organization. An employment contract with the client organization is highly attractive; the manager at the client organization can pick and choose among agency workers. Some of the agency workers have been at the client organization for six years. The HR manager at the client organization describes the situation when they announced 13 jobs openings.

All [agency workers] want to have this employment [at the client organization]; 80 people applied. Individuals who did not get the job were crying; there were many emotions involved... We gave very much importance to personal characteristics, we do a lot of changes, and we want people who easily deal with changes. And we also looked for individuals with leadership traits... We did not employ those with the longest assignments, nor those who were most multi-skilled. (HR manager SE)

In the plant there is no natural career path from the agency to being employed by the client organization. The union has no say in these decisions and the local trade union 
representative did not consider to intervene in these issues with references to the employer's right to freely choose who to employ. In June 2016 the share of temporary agency workers was $37 \%$. The union's response to temporary agency workers is quite ambiguous, demonstrating both positive and negative attitudes. The union expressed a positive attitude to using temporary agency workers during peaks of production. However, the national regulation allows the client organization to hire agency workers for any reason making extensive hiring possible, which was strongly criticized by the union. According to the union representative, the use of agency workers is too extensive, and the union would prefer direct hiring. However, the attitude to the agency workers at the client organization is supportive.

We don't make any distinction. For me, they [temporary agency workers] are union members as much as the others [client organization employees]. (Union representative $S E$ )

The supportive attitude is evident in that the agency workers are welcome to take part in union meetings, although they cannot as client firm employees use working time for these meetings. The local union at the client organization represents them in issues related to the work during the assignment. However, when it comes to questions about wages, the duration of the assignment or dismissals, the local union has no say. The local union at the client organization has, according to the legislation, no mandate to represent staff from temporary work agencies in issues concerning the employment relationship. This means that when it comes to job security, this is not a question for the local union at the client organization but at the agency (Swedish Code of Statutes, 1982:8, Section 29). However, in the agency used by the client organization there is no local union 
representing the agency workers at the agency, and hence, the agency workers have to turn to the union representative at regional level.

The close cooperation between the client organization and the agency entails some stability for the agency workers; most agency workers' assignments are long term. This could be called assignment security. However, at the time of the interview with the manager at the agency in 2016, the client organization's need for agency workers was decreasing, and one third of them were to leave the assignment at the client organization. This in a nutshell illustrates the buffering function of agency workers - when demand decreases, the client organization can easily decrease the buffer. The agency workers leaving the client organization are still employed by the agency; they have open-ended contracts, which should provide job security. Thus, the agency has to find new assignments at other client organizations, and the agency worker has to be mobile. However, the client organizations have the right to choose whom they want, and can change agency workers at will:

In case the client organization is not satisfied [with the agency worker], we have to listen to that. Because they decide who they want to hire. (Manager at the work agency)

The trade unions do not have any say in these decisions. From the union perspective, this entails a feeling of insecurity for temporary agency workers: 
The temporary agency workers are terrified not to behave properly. They know that they are just a phone call away [from being replaced]. (Union representative at regional level, If Metall)

At the time of the interview there was increased demand in the business, and the manager at the agency was quite confident about finding new assignments for those who would be leaving the client organization. However, during recessions the demand for agency workers decreases, making it difficult to find other client organizations. Accordingly, long tenure at the agency hardly produces security. In case of staff cuts, the employer has to provide notice and call for negotiations. According to Swedish legislation, tenure is the main principle when deciding on dismissals. The union representatives interviewed claim that the principle of 'last hired, first fired' is difficult to maintain in the temporary agency sector in general due to the business relation, as the client organization decides whom they want to hire independently of their tenure at the work agency. The agency in this case study has not made any staff cuts since the crisis of 2008.

This case illustrates that even though the temporary agency workers have open-ended contracts with the agency, their function as a buffer makes them vulnerable in downturns.

\section{Evidence from the Belgium case}

The Belgium case organization produces low-tech parts for the automotive industry. As a supplier of the big automotive groups, high levels of flexibility - especially in terms of just-in-time delivery and flexible volumes (changeable week by week) - are required. Although legislation guarantees equal treatment - which means that wages and working 
conditions of regular and agency staff are almost the same (the only differences are voluntary benefits given by the Belgium case organization) - local unions started to actively engage in local bargaining to improve the agency workers' situation. This was possible because of the specific status of the agency workers; that is, on the one hand, they are covered by a Joint Committee (no. 322) establishing regulation. On the other hand, regulation foresees that as soon as agency workers leave the agency and are sent to a client organization, they are represented in their client organization, too. Hence, local unions have a mandate to represent not only the staff of the client organization, but also the agency workers. Moreover, and this corresponds to the unions' general policy, they want to avoid competition between different groups of workers at any price, implying that wages, working conditions and voluntary benefits need to be the same.

We need to make sure that agency and regular workers have the same rights. This also includes voluntary benefits, such as meal vouchers or the yearly Christmas present. We achieved an agreement with management on that - every agency workers who has worked here for three months has the same benefits as regular workers. (Local unionist)

Management agreed to the local unions' demands, as assignments tended to be shorter than three months, which limited the number of agency workers entitled to voluntary benefits. When flexibility pressures mounted in 2002, management started hiring high numbers of blue-collar agency workers to deal with fluctuations in production. While assignments tended to be short in the beginning, the duration got longer and longer, sometimes even up to two years without clear prospects of contractual upgrades. At the same time, management felt challenged by the situation, because the sheer number of 
agency workers adversely affected the efficiency of production and administrative processes.

At first in late 2003, local unions demanded a quota to limit the use of agency contracts to avoid an abuse of this flexible form of work. In their view, the situation particularly got out of control in terms of pressure at work and stress for the whole workforce, as production volumes steeply increased. Specifically, the huge number of agency workers entering the company meant that not all of them were skilled for the job, which led to quality issues and the need for regular workers to train them during their working hours. Since no compromise was found locally, and the dispute regarding the quota became severe, management and local unions had to go into mediation. As a result of the mediation in 2004 , a $15 \%$ flexibility quota was implemented, consisting of $10 \%$ fixedterm and 5\% agency workers. Management accepted the agreement mainly because it feared an even stronger regulation of agency work, since

There are companies in Belgium in which agency work cannot be used at all due to the unions and their strength. (Local HR Manager)

While this represented another step in terms of workplace regulation on agency work, in the following years local unions pushed further to achieve higher levels of security for agency staff, regarding both job security and training. On the one hand, they demanded a system of subsequent contractual upgrades in accordance with the (nowadays) collectively negotiated stepping-stone motive of using agency work. On the other hand, an arrangement regarding training was demanded. This would limit potential differences between regular and agency staff and improve the skills and thus the employability of 
agency workers. After the previous dispute and mediation, and considering the fact that the negotiated agreement worked well in practice, management was open to negotiate about these issues, especially because of the need to retain skilled workers.

Obviously, you want to retain your skills, so you cannot constantly have your skills go out, and then you maybe don't get the right skills anymore. (Local HR Manager)

Furthermore, management also saw the potential benefits of an agreement on formalized employment trajectories with subsequent contractual upgrades. On the one hand, this had positive effects on the motivation and commitment of agency workers due to the prospect of being hired directly by client organization. On the other hand, the agency contract represented a trial or probation period that could be used to identify potentially good workers for contractual upgrades. Due to such shared interests, an agreement stating that agency contracts would be upgraded to fixed-term (after 6-12 months) and permanent contracts (after two years) was reached, giving clear career prospects to agency workers in the client organization. In terms of training, there was no formal workplace agreement, since this was handled based on the company's and workers' individual needs. In any case, each agency worker would receive a safety briefing and on-the-job training before starting the assignment.

At first, agency workers get relevant information from their agency. Then they directly go into the on-the-job training program that is set up in the department they work for. They get training, but to a limited extent because they are the most flexible group of people in our plant which means that in theory, they can go from 
one department to another pretty quickly. But we also have agency workers with very stable working patterns. Those are mostly well-trained and of a high addedvalue for us. (Plant manage)

Overall, the fact that agency workers in the client organization were represented by the local unions was crucial for their security. Although regulation set equal treatment between agency and regular workers, local unions' used their mandate to limit competition and increase equality between different groups of workers by extending voluntary benefits to agency workers and by negotiating a system of formalized employment trajectories. This remarkably increased agency workers' security and offered prospects of being hired directly by the client organization in the long run.

\section{Discussion}

Previous research shows that temporary agency workers perceive less job security compared to others (Aletraris, 2010; De Cuyper et al., 2009; de Graaf-Zilj, 2012; Forte and Slater, 2005; Håkansson et al., 2012; Morris, 1999). This article adds to existing literature identifying factors explaining the lack of security for temporary agency workers. In particular, it sheds light on how regulation on national and sectoral levels as well as practices providing for a collective voice shape how agency workers are used at the workplace level, which in turn produce insecurity.

\section{National regulation shaping workplace practices}

In Sweden, the national regulation permits indefinite length of assignments; accordingly, extensive hiring at workplace level is possible. The Swedish case illustrates such 
extensive use where the agency workers prevalently are used on long-term assignments to constitute a buffer that protects the client organization from dismissing their own employees and by that avoiding disruption when reducing staff. In companies using agency workers strategically as a buffer (Holst et al., 2010) the job security for client organization employees increases. However, for the temporary agency workers, the termination of an assignment should not entail job insecurity. The Swedish national regulation admits open-ended contracts for agency workers, in case one assignment is terminated the agency should assign the agency workers to other user firms. Hence, in principle agency workers should have the same job security as other employees. This is in line with the classification by Regalia (2013) - sharing the work between several employers entail job security for the employee.

However, our analysis reveals that when the temporary agency workers are used in large scale as a buffer, the client organization has no incentives to transfer the agency workers to ordinary staff. Hence, the agency workers remain in employments with the agency. In case of a recession, it might be difficult to find other user firms resulting in a redundancy at the agency. According to the Swedish employment protecting legislation, the last employed should be the first to leave. Nevertheless, the business relation between the temporary agency and the client organization puts a lot of pressure on the agency to withdraw from this principle. Thus, negotiations about redundancies at the temporary work agency require strong union power.

The Swedish case also illustrates how the client organization employs some of the temporary agency workers. For the agency workers concerned, it implies increased job security as they by that no longer are part of the buffer. In contrast to the Belgian case, 
the union at the Swedish client organization has no say on this issue, since agency workers according to regulation are not represented at the client organization. Thus the employer at the client organization easily picks and chooses whom to employ. This pathway to security is different from what Regalia (2013) found, in our case there is no pact between the union and the employer, on the contrary it is fully accepted by the union that issues on recruitment is solely an employer prerogative, why the achieved security doesn't follow any principle of tenure or order.

According to the regulation in Belgium, conversely, it is not possible to achieve job security for temporary agency workers, because these workers by law can only obtain temporary contracts. Their job security can only be achieved by transforming the contract with the agency to an employment contract with the client organization. As the Belgian case illustrates a strong local union at the client organization, with an inclusive stance towards agency workers, is a prerequisite. However, our comparison shows that this is not sufficient; this transformation presupposes collective representation rights for agency workers that give the local client organisation union and works council possibility to represent agency workers on assignment. The union's response to temporary agency workers can be understood in relation to the national regulation of the sector.

\section{Job security and representation security intertwined}

The Swedish case illustrates the ambivalence in the local union's attitude to temporary agency workers. As extensive use is possible, the union's strategy is to accept temporary agency workers in peak periods but limit the use of agency workers as a buffer. This twosided strategy was also found in Bergström and Styrhe (2010), illustrating the local 
union's efforts to safeguard its own members (client organization employees) while at the same time trying to embrace agency workers in the union's work. Relating this response to the model by Heery (2004), we find similarities to both replacement and restriction. Hence, the union is striving to improve the working conditions for temporary agency workers, but at the same time they accept that the agency workers safeguard the regular workers in case of a downturn.

In Belgium, it may be argued that the inclusive union's response to temporary agency workers is the natural response to the strong national regulation of the agency industry. The union's effort to transfer agency workers to client organization employees is bounded legally. The unions' argument for restricting the use of agency workers is not to safeguard the client organization employees but is a negative attitude to agency work. According to the union, agency workers are treated badly and should be protected. This response is close to what Heery calls replacement. In the Belgian case, this means replacement from being an agency worker to a client organization employee. As illustrated, access to collective voice for agency workers at the client organization was crucial for the transition of contracts and the opportunity to attain job security.

The Swedish case shows that the temporary agency workers lack collective voice. According to national regulation (Swedish Code of Statutes, 1974:358), union representation is related to the employer relationship. Even though the union at the client organization welcomes agency workers and wants to represent them, this is only possible in issues relating to the management relation. On issues concerning job security the agency worker has to turn to the union representative at regional level, who witnesses the difficulties in following the labour law stipulating the tenure principle. The representation 
structure is thus restricting the union's strategies no matter the inclusive stance - they are by law prevented from representing agency workers in issues related to job security. This illustrates how job insecurity and representation insecurity are intertwined in temporary agency work.

Conversely, in Belgium job insecurity for agency workers is the result of the temporal character of the employment contract. This is because of the relatively high level of regulation of the agency industry, which is the result of the law, collective agreements and collective representation rights being guaranteed in both the client organization and the agency. The unions' replacement response in Belgium is functional to the regulatory logic that makes job security for agency workers impossible but promotes transition of employment to client organizations.

\section{Conclusion}

Explanations for temporary agency workers' perception of job insecurity have mainly been sought in different working conditions and social policy for agency workers in comparison to other employees. Comparative studies of how different regulatory systems shape this insecurity are scarce. To understand how job insecurity for temporary agency workers is produced, we have to go beyond the national and industrial regulation and analyse how this regulation shapes workplace practices and access to a collective voice. Thus, connecting the national and workplace levels is crucial in understanding job insecurity for agency workers. 
Job insecurity is shaped not only by the type of contract; it is primarily formed by how the national regulation, inclusive of collective bargaining and representation structures, shapes the modalities in accordance to which temporary agency workers are used at workplaces. Specifically, national regulations and collective structures for representation shape the unions' possibilities to represent the agency workers and their approaches to agency workers. Hence findings presented in this paper add to the understanding of the conditions contributing to security for agency workers. Conversely to Regalia (2013) we found that achieving job security by transforming agency workers to client organization employees is not only or just about unions building pacts with the employer but it requires a strong structure for the representation of the agency workers at the client organisation. The comparative findings clearly illustrate that this is the case in Belgium but not in Sweden, thereby explaining the differences in security/insecurity across (and within) the two countries. However, our study also show that a strong representative union structure at the client organization, with an inclusive stance towards agency workers, is a prerequisite; but it is not sufficient. This article shows that it is the regulations that give temporary agency workers on assignment access to a collective voice via the local client organization that is crucial for job security

\section{References and sources}

Aletratis, L. (2010) How satisfied are they and why? A study of job satisfaction, job rewards, gender and temporary agency workers in Australia. Human Relations, 63, 11291155

Allvin, M., Jacobsson, A. \& Isaksson, K. (2003) Att avgränsa det gränslösa sjuksköterskearbetet. En intervjustudie om sjuksköterskors villkor och valmöjligheter $i$ bemanningsbranschen. Solna: Arbetslivsinstitutet 
Arrowsmith, J. (2006). Temporary agency work in an enlarged European Union. http://www.eurofound.europa.eu/pubdocs/2005/139/en/1/ef05139en.pdf

Bemanningsföretagen (2006) Bemanningsföretagens utveckling , 4:e kvartalet 2005. Stockholm: Bemanningsföretagen.

Bemanningsföretagen (2009) Antal anställda och penetrationsgrad $i$ bemanningsbranschen 2008. Bemanningsföretagens utveckling. Stockholm: Bemanningsföretagen.

Bemanningsföretagen (2011) Antal anställda och penetrationsgrad $i$ bemanningsbranschen 2010. Stockholm: Bemanningsföretagen.

Bemanningsföretagen (2012) Antal anställda och penetrationsgrad $i$ bemanningsbranschen 2011. Stockholm: Bemanningsföretagen.

Bemanningsföretagen (2013) Bemanningsindikatorn Q4 2013. Stockholm: Bemanningsföretagen.

Bemanningsföretagen (2014) Bemanningsindikatorn Q3 2014. Stockholm: Bemanningsföretagen.

Bemanningsföretagen (2015) Bemanningsföretagens årsrapport 2014. Stockholm: Bemanningsföretagen.

Bemanningsföretagen (2016) Bemanningsföretagens årsrapport 2015. Stockholm: Bemanningsföretagen.

Benassi, C., Doellgast, V., \& Sarmiento-Mirwaldt, K. (2016). Institutions and Inequality in Liberalizing Markets: Explaining Different Trajectories of Institutional Change in Social Europe. Politics \& Society, 44(1): 117-142. doi:10.1177/0032329215617466

Bergström, O. \& Storrie, D. (eds.) (2003) Contingent Employment in Europe and the United States. Cheltenham: Edward Elgar.

Bergström, O., and Styhre, A. (2010) Irish Butchers Rather Than Irish Meat: Trade Union Responses to Agency Work in Sweden. Journal of Industrial Relations, 52(4): 477-490

Björkemarken, M. (2012), Bemanningsbranschen i Västsverige - Fackliga Erfarenheter [The Staffing Industry in Western Sweden - Trade Union Experiences], Swedish Trade Union Confederation, LO-distriktet i Västsverige. 
Burroni, L., and Carrieri, M. (2011) Bargaining for social rights (BARSORI) country report Italy. http://uva-aias.net/uploaded_files/regular/BarsoriReport-Italy.pdf

Chung, H. (2016). Dualization and subjective employment insecurity: Explaining the subjective employment insecurity divide between permanent and temporary workers across 23 European countries. Economic and Industrial Democracy [Online]. Available at: http://dx.doi.org/10.1177/0143831X16656411.

Ciett (2013) The Agency Work Industry around the World. Economic Report. 2013 Edition

Ciett (2014). Ciett economic report 2013. http://www.ciett.org/fileadmin/templates/ciett/docs/Stats/Economic_report_2014/CIET T_ER2013.pdf

De Cuyper, N., Notelaers, G. \& De Witte, H. 2009. Job Insecurity and Employability in Fixed-Term Contractors, Agency Workers, and Permanent Workers: Associations with Job Satisfaction and Affective Organizational Commitment. Journal of Occupational Health Psychology, 14, 193-205

Clauwaert, S. (2000) Survey of legislation on temporary agency work. http://library.fes.de/pdf-files/gurn/00326.pdf

Doerflinger N. And Pulignano V. (2015) Temporary agency work and trade unions in comparative perspective. A mixed blessing?, Journal of Workplace Rights, 5(2):1-10

Croucher, R., and Brewster, C. (1998) Flexible working practices and trade unions. Employee Relations, 20(5): 443-452

Davidsson, J.B., and Emmenegger, P. (2013) Defending the organization, not the members: Unions and the reform of job security legislation in Western Europe. European Journal of Political Research, 52(3): 339-363

De Graaf-Zilj, M. 2012. Job Satisfaction and Contingent Employment. EconomistNetherlands, 160, 197-218

Delbar, C., and Léonard, E. (2002) Le travail intérimaire. Courrier hebdomadaire no. 1778, Centre de Recherche et d'Information Socio-Politiques (CRISP), Bruxelles 
Eisenhardt, K. (1989) Building theories from case study research. Academy of Management Review, 14(4): 532-550

Emmenegger, P., Häusermann, S., and Palier, B. (2012) The Age of Dualization: The Changing Face of Inequality in Deindustrializing Societies. Oxford: Oxford University Press

Elicioglu, E. (2010) Producing Precarity: The Temporary Staffing Agency in the Labour Market. Qualitative Sociology 33:117-136

Forde, C. and G. Slater (2005) Agency working in Britain: Character, consequences and regulation. British Journal of Industrial Relations, 43: 249-271

Gazier, B. (2007) "Making transitions pay": the "transitional labour markets" approach to "flexicurity". In Jörgensen, H. and Kungshøj Madsen, P. Flexicurity and beyond. Finding a new agenda for the European Social Model. Copenhagen: DJØF Publishing.

Hall, R. (2006) Temporary agency work and HRM in Australia. Personnel Review, 35, $158-174$

Heery, E. (2004) The trade union response to agency labour in Britain. Industrial Relations Journal 35:5. 434-450

Holst, H., Aust, A. \& Pernicka, S. (2008) Kollektive Interessensvertretung im strategischen Dilemma - Atypisch Beschäftigte und die "dreifache Krise" der Gewerkschaften. Zeitschrift für Soziologie, 37(2): 158-176

Holst, H., Nachtwey, O. and Dörre, K. (2010). The strategic use of temporary agency work: functional change of a non-standard form of employment. International Journal of Action Research, 6: 108-138

Houwing H. \& Vandaele, K. (2011). Liberal convergence, growing outcome divergence? Institutional continuity and changing trajectories in the "Low Countries". In U. Becker, The changing political economies of small West European countries (pp. 125-148). Amsterdam: Amsterdam University Press

Håkansson, K. \& T. Isidorsson (2014) Trade union response to agency labour in Sweden. Industrial Relations Journal, 45(1): 22-38

Håkansson, K. \& T. Isidorsson (2015) Temporary Agency Workers-Precarious Workers? Perceived Job Security and Employability for Temporary Agency Workers and 
Client Organization Employees at a Swedish Manufacturing Plant. Nordic journal of working life studies, 5(4): 3-22

Håkansson, K, T. Isidorsson \& H. Kantelius (2012) Temporary agency work as means of achieving flexicurity? Nordic journal for working life studies, 2(4): 153-169

Håkansson, K, T. Isidorsson \& P. Strauss Raats (2013) Arbetsmiljö för hyresarbetskraft - inhyrdas fysiska och psykosociala arbetsmiljö. Arbetsmiljöverket 2013

Kalleberg, A. \& P. Marsten (2005) Externalizing organizational activities: where and how US establishments use employment intermediaries. Socio-Economic Review, vol 3, issue $3,389-416$

Kalleberg, A. L. (2009) Precarious work, insecure workers: employment relations in transition. American Sociological Review, 74(1): 1-22. doi: http://dx.doi.org/10.1111/1467- 8543.00211.

Kjellberg, A. (2011) The decline in Swedish union density since 2007. Nordic Journal of Working Life Studies, Volume 1, Number 1, August 2011

Kjellberg, A. (2016). Parternas organisationsgrad och kollektivavtalens utbredning. i B. Andersson (Ed) Avtalsrörelsen och lönebildningen 2015. (s. 42-48). Medlingsinstitutet

Leschke, J., Schmid, G. and Griga, D. (2007) On the marriage of flexibility and security: Lessons from the Hartz-reforms in Germany. In Jörgensen, H. and P. Kungshøj Madsen Flexicurity and beyond. Finding a new agenda for the European Social Model. Copenhagen: DJÖF Publishing.

McKenzie R., Forde, C., Robinson, A., Cook, H., Eriksson, B., Larsson, P. and Bergman, A. (2010) Contingent work in the UK and Sweden: evidence from the construction industry Industrial Relation Journal, 41(6): 603-621

Morris, J. A. 1999. Injury experience of temporary workers in a manufacturing setting. Factors that increase vulnerability. AAOHN J, 47, 470-478

OECD (2013), OECD Employment Outlook 2013, OECD Publishing, Paris, available at: http://dx. doi.org/10.1787/empl_outlook-2013-en

Olsen, K. (2005) Unions' dilemma when firms use employment intermediaries. European Sociological Review, 21(3): 289-300 
Pulignano, V., Doerflinger, N. (2013) “A head with two tales? Trade unions' influence on addressing temporary agency workers security while enhancing flexibility in Belgian and German workplaces", International Journal of Human Resource Management, 24 (22), 4149-4165.

Pulignano V. and Doerflinger N. (2017) "Changing labour markets and solidarity: comparing local unions' responses to management flexibility strategies in the German and Belgian metalworking and chemical industries" In Doellgast V. Lilie N. And Pulignano V. (eds) Reconstructing solidarity: Labour unions, precarious work, and the politics of institutional change in Europe, Oxford: Oxford University Press

Pulignano V. and Signoretti A. (2016) "Union strategies, national institutions and the use of temporary labour in Italian and US plants", British Journal of Industrial Relations, 54(3): 574596

Purcell, J., Purcell, K., Tailby, S. (2004) Temporary work agencies: Here Today, Gone Tomorrow? British Journal of Industrial Relations Vol 42, issue 4, 705-725

Regalia, I. (2013) Regional and Local Experiments for Labor Market Policy in Europe. In Stone, K. \& Arthurs, H. (eds) Rethinking workplace regulation. Beyond the standard contract of employment. New York: Russell Sage Fundation.

Standing, G. (2011) The Precariat: The New Dangerous Class. London: Bloomsbury Academic

Storrie, D. (2007) "Temporary Agency Work in the European Union - Economic Rationale and Equal Treatment”. in: Furåker, B., Håkansson, K. \& Karlsson, J. C. (eds.) Flexibility and Stability in Working Life. Houndmills, Basing-stoke, Hampshire and New York, NY: Palgrave Macmillan

SCB (2014) Statistisk årsbok 2013. Statistiska centralbyrån. Stockholm: SCB, Statistics Sweden

Schmitter, P.C., and Streeck, W. (1999) The organization of business interests: studying the associative action of business in advanced industrial societies. MPIfG discussion paper, 1999/1

Staffing Agreement (2016), Arbetare. Avtal för Bemanningsföretag. Avtal Tecknat 2016 Giltighetstid: 2016-05-01-2017-04-30, Bemanningsföretagen, Fastighetsanställdas Förbund, GS - Facket för skogs, trä- och grafisk bransch, Handelsanställdas förbund, Hotell och Restaurang Facket, IF Metall, SEKO -Service och Kommunikationsfacket, Svenska Byggnadsarbetareförbundet, Svenska Elektrikerförbundet, Svenska 
Kommunalarbetareförbundet, Svenska Livsmedelsarbetareförbundet, Svenska Musikerförbundet, $\quad$ Svenska $\quad$ Målareförbundet, $\quad$ Svenska Pappersindustriarbetarförbundet,Svenska Transportarbetarförbunder (Collective Agreement for Blue-collar workers working for staffing agencies from 1 May 2016-30 April 2017, Swedish Staffing Agencies, and 14 Blue-collar Trade Unions within the Swedish Trade Union Confederation), Stockholm.

Swedish Code of Statutes 1974:358. Trade union representatives status at the workplace act, No 1974:358, Swedish Parliament, Stockholm

Swedish Code of Statutes 1993:440. The Provare Employment Agencies and Temporary Labour Act, No. 1993:440, Swedish Parliament, Stockholm

Swedish Code of Statutes 1982:80. The Employment Protection Act, No. 1982:80, Swedish Parliament, Stockholm.

Swedish Code of Statutes 2012:854. The Agency Work Act, No. 2012:854, Swedish Parliament, Stockholm.

Vandaele, K. (2006) A report from the homeland of the Ghent system: unemployment and union membership in Belgium. Transfer, 13(4): 647-657 